\title{
From Cosmopolitanism to Planetary Conviviality: Suneeta Peres da Costa and Michelle de Kretser
}

\author{
Alejandra Moreno Álvarez \\ University of Oviedo \\ morenoalejandra@uniovi.es
}

\begin{abstract}
Copyright $\odot 2017$ Alejandra Moreno Álvarez. This text may be archived and redistributed both in electronic form and in hard copy, provided that the author and journal are properly cited and no fee is charged, in accordance with our Creative Commons Licence.
\end{abstract}

\begin{abstract}
Veronica Brady, vigorous supporter of Aboriginal causes and deeply concerned with social-injustice issues, underlined that Anglo-Australians were to be excommunicated from the land until they would come to terms with it and its first peoples (in Jones 1997). Nearly twenty years after this statement was postulated, it is my purpose in this paper to look at the land from an Anglo-Australian and nonIndigenous Australian perspective in order to assess if Australian contemporary society has moved beyond what Brady considered a "super ego status" and reconciled to the presence not only of its Indigenous, but also its non-Indigenous others. To do so I will exemplify novels which are part of and influenced by the matrix of relations and social forces in which non-indigenous Australian writers are situated on, including Suneeta Peres da Costa's Homework (1999) and Michelle de Kretser's Questions of Travel
\end{abstract} (2013).

Key words: Cosmopolitanism; hybridity; postcolonialism; South Asian-Australian Literature.

In 2009 the Australian media coined the term "curry bashing" to refer to a wave of attacks on Indian students which prompted demonstrations in Melbourne and Sydney and remonstrations from India. Rudyard Kipling's (in)famous ballad resonated on both sides and a debate erupted as to whether Australia was still a racist society that reacted to the presence of these Indian students-migrants along the colonial binary of East vs West. Against this logic, it can be argued that Australia has never been a cultural monolith, nor the location of an immutable and monochromatic society. It is rather, a discursive construction in which incessant contestations of meanings are taking place. It is the land of the Indigenous population, of colonists, settlers, but also of countless migrants of European and Asian descent, including asylum seekers (mainly from Iraq, Afghanistan and Sri Lanka) and international students. Despite the frantic and strident attempts to restore the one white nation of the past, many still prefer to see Australia as a multilayered society. As regards literary creation and criticism this implies to challenge and negotiate the metanarrative of Australian literature from a multiplicity of perspectives. 
In the case of the South Asian-Australian population, which this article will primarily be focussed on, it is from 1970 onwards, with the adoption of the official multicultural policy, that a large number of people of South Asian origin migrated to Australia. Time enough for South Asian-Australian literature to emerge and to achieve "in a relatively short space of time, ... commercial and critical success" (Athique in Sarwal 2013: 24). Australian writers of South Asian ancestry, such as Mena Abdullah, Suneeta Peres da Costa, Chitra Fernando, Yasmine Gooneratne, Adib Khan, Michelle de Kretser, Bem Le Hunte, Chandani Lokugé, or Christine Mangala, to name but a few, use literature as an instrument to voice often complex discursive strategies, such as belonging, inbetweenness, cosmopolitanism or planetarism. These authors negotiate their spatial identities within the g/local and continue to construe the past and the present. The Australian land where first peoples, colonialists, settlers and migrants live form a palimpsest of hybrid subjects for whom conviviality or planetary citizenship become, at certain points, unavoidable.

At the turn of the century, writers and critics were quick to develop theories and terms in line with a global political agenda. As Alfred Hornung highlights in "Planetary Citizenship" (2011), "[t]hey ranged from the willing embracement of globalization to new concepts of cosmopolitanism, programmatically announced in "The Cosmopolitan Manifesto" by the German sociologist Ulrich Beck, taking up Immanuel Kant's idea of hospitality granted to all strangers" (in Lenz 2011, pp. 39). In this line, Professor Renate Brosch, in the keynote session entitled "Fictions of Planetary Conviviality-Towards a Cosmopolitan Practice", given at the International Australian Studies Association Biennial Conference "Friends, Foes and other Intimacies" held at the University of Tasmania in December 2014, defined cosmopolitanism as the interaction between self and other. Brosch insisted that there is no human self in the absence of the other since, as defined by Levinas, the concept of the self requires the existence of the Other as the counterpart entity required for defining the Self, "The origin of authentic ethical behavior is not from the self but from the Other" (European Journal of Psychotherapy \& Counselling 2005, pp. 1). Nonetheless, Brosch maintained that cosmopolitan novels are still in process due to the difficulty of writing outside the dominant discourse. Another theoretical term that has been suggested is that of "planetary", adopted by Paul Gilroy (2005), from the position of race, Gayatri Spivak (2003), from a post-Marxist perspective, and Ursula Heise (2008) from an environmentalist point of view. Gayatri Spivak's use of the expression planetarity is motivated by her concern for a new humanist attitude toward the less fortunate Others. She considers planetary as "an alternate term for continental, global, worldly" since it encloses the human concern: "To be human is to be intended toward the other" (2003, pp. 73). Michelle de Kretser and Suneeta Peres da Costa, used here as exponents of South Asian-Australian writers, seem to claim for a theoretical shift which ranges from cosmopolitanism to planetary conviviality. According to this logic the characters which they create are empathetic universals whose embodiment, spatiality and intersubjectivity is constituted in relation to others; where being human is being conhuman.

This article will raise questions such as the need to redefine and review the Australian literary canon, and with it, the meaning of Australianness. Authors such as Michelle de Kretser's Questions of Travel (2013) and Suneeta Peres da Costa's Homework (1999) 
name what is for their non-Caucasian characters "Australia" in the contemporary entangled milieu. In Gail Jones' interview "Veronica Brady" (1997), Veronica Brady emphasizes how Australians ought to be excommunicated from the land:

until we come to terms with the land and its first peoples. I cannot see how you can say that you believe in the Christian story if you don't believe that God is present in each individual human being, and where an individual human being is being degraded and humiliated then the divine form becomes degraded. But on the other side, I am also very convinced of the holiness and sacredness of the other. (pp. 141)

This "other" will be here understood as an Australian of South Asian lineage. According to Amit Sarwal, migration, in this rapidly globalizing world, has not only spread the roots of diaspora deeper but has also put it on a global level by concretizing it as a natural and inevitable result (Sarwal 2013, pp. 1, my emphasis). In the case of the South Asian diaspora, and following Sutama Gosh, "neither academics nor the general population seems to be sure of where 'South Asians' are from" $(2012,36)$. Most researchers coincide that India, Pakistan, Bangladesh and Sri Lanka are an intrinsic part of South Asia, while Afghanistan, Nepal, Bhutan and Myanmar are both included and excluded from it. Some scholars agree that those who have an Indian origin (British India) should be considered "South Asians" (Kurian 1991). Others consider those from the Indian subcontinent as "South Asians" (Riaz 2010), excluding West Indians, Fijians and East Africans (Dasgupta 1994). This turmoil over the geographic location of "South Asia" causes us to raise the question if "South Asian" is itself a meaningful category and if so, if this categorisation is another example of the Others having their identities homogenised.

South Asian-Australian authors are considered diasporic due to their association with a geographical space of lineage which differs from the one they are living in. This classification is a strategy within the political project of Othering so as to map ex-colonial non white bodies. In fact, authors such as de Kretser and da Costa offer hybrid literary spaces where Australia becomes multilayered without the need to classify these authors as South Asian-Australians. Since, as Gosh underlines, "'South Asian' is a category whose history and commonalities has been determined by outsiders, it has not been internalised by its intended subjects" (2012, pp. 48). Australian authors of South Asian descent have played, and continue with, an important role in the spreading of new ideas and thoughts. We all know that the history of migration from South Asia is rich in tales and metaphors of its civilization and, following Judah Waten, its "imperishable peoples" influence lies far beyond their own subcontinental shores (in Sarwal 2013, pp. 26). These people are many times drawn as a Ficus benghalensis, commonly known as the Indian banyan, Bengal fig or Indian fig. The roots of this tree propagate downwards as aerial roots. Once these roots reach the ground, they grow into woody trunks, which makes the original trunk blurred as all the scattered stems seem to be as important. Thus, the banyan tree and its branches take root in different soils, through different routes, which explains why it has been used by many to represent the migratory movement across borders, although there are many interpretations for this metaphor. On the one hand, Hugh Tinker emphasizes that to comprehend what a banyan tree represents, you must know its principle stem and soil, but you must also follow its growth of its different shapes, to 
conclude by saying, quoting Rabindranath Tagore, that "the civilization of India, like the banyan tree, has shed its beneficent shade away from its own birth place" (in Tinker 1977, pp. iii). On the other hand, Salman Rushdie considers roots a "conservative myth, designed to keep us in our places":

I am comparing gravity with belonging. Both phenomena observably exist: my feet stay on the ground, and I have never been angrier than on the day my father told me he had sold my childhood home in Bombay. But neither is understood. We know the force of gravity, but not its origins; and to explain why we become attached to our birthplaces we pretend that we are trees and speak of roots. Look under your feet. You will not find gnarled growths spouting through the soles. Roots, I sometimes think, are a conservative myth, designed to keep us in our places. (Rushdie 1985, pp. 90-91)

Migration represents, as Sarwal underlines, transgression and thereby a loss of a "conservative" cultural identity on both parts, the migrant and the native (2013, pp. 26). As Annette Corkhill suggests, the feeling of dislocation, so frequently a part of the immigrant experience, can be overcome by "virtue of a commitment to loving and working the soil of the adopted homeland" (1995, pp. 37). What matters in the image of the nomadic subject is not the literary act of travelling or displacement; rather, it is the development of a consciousness which "combines coherence with mobility" (Braidotti 1994, pp. 31). The nomadic subject "aims to rethink the unity of the subject... without dualistic oppositions" (Braidotti 1994, pp. 31). Therefore, the nomadic subject undoubtedly inscribes new ways of being. As Rushdie corroborates:

A full migrant suffers, traditionally, a triple disruption: he loses his place, he enters into an alien language, and he finds himself surrounded by being[s] whose social behaviour and code is very unlike, and sometimes offensive to, his own. And this is what makes migrants such important figures: because roots, language and social norms have been three of the most important parts of the definition of what it is to be a human being. The migrant denied all three, is obliged to find new ways of describing himself [or herself], new ways of being human. (1991, pp. ix)

Like Rushdie, many diasporic writers use literature to address new cultural identities, subverting the postcolonial, alongside celebrating planetary hybridity, creating multiple and global spaces where meeting-point cultures of the global north and the global south, and the global west and global east, merge, so as to leave aside the inbetweenness that has until now constricted them. Aerial roots, which form the banyan tree I have referred to, give rise to "newer and newer trunks, which over generations, make it almost impossible to tell the "mother trunk" (Prasad 1999, pp.12). The historical genealogy, the mother trunk, that first inscribed the inbetweenness of South Asian-Australians, has differed extensively from second generations. Nonetheless, the movement out of India to other parts of the world began more than 2000 years ago:

Indian merchants traded in East Africa and the Persian Gulf, and Buddhist pilgrims migrated to Southeast Asia and China. In the $19^{\text {th }}$ and $20^{\text {th }}$ centuries, 
however, a very different kind of migration took place. Large number of Indians relocated to various countries, particularly to other parts of the British empire. These resettlements began the growing, widely diverse, emigrant population that is sometimes called the "Indian diaspora". (Prasad 1999, pp. 12)

In the case of Australia, the largest number of people of South Asian origin have mainly migrated to Australia since the 1980s. Nevertheless, Adrian Mitchell remarks that the Australia-India connection begins with the First Settlement, "with the transport of ships heading off to India when once the convicts had been off-loaded; and soon after that the foundling colony was sending off to India for grain" (2000, pp. 19-20). In the early nineteenth century, a significant number of Indians were brought to Australia to work as labourers and more Indians were brought thereafter to run the "Camel trains". Samia Khatun in her PhD dissertation "Camels, Ships, Trains: Translation Across the 'Indian Archipelago' 1860-1930" (2012) studies cross-cultural interactions arising from the scarcely but historically significant South Asian presence in Australia in the late nineteenth and early twentieth centuries. Khatun highlights how the best known South Asian migrants to Australia were the so-called "Afghan cameleers," recruited not only from Afghanistan but other parts of British India. Thanks to their skilfulness in camel handling:

these men proved instrumental in establishing a viable pastoral industry in the arid interior of the continent. Camel trains supplied remote sheep stations with necessary rations and served as the first link in a transportation network of railways and steamships that conveyed wool to distant markets. Although individual cameleers amassed personal fortunes through shrewd investments in the transportation business, as a whole this community of men remained economically humble and marginal to white settler society while enjoying ambivalent relations with aboriginal communities. (Foster 2012)

Punjabis also arrived in the late nineteenth century to take part in the gold rush in Victoria or to work on the banana plantations in Southern Queensland. This first wave was followed by immigrants arriving through World Wars I and II, not for nothing Indian soldiers were present in Gallipoli fighting for the British armed forces alongside Australian diggers. After India's Independence from Britain, another important group of South Asians, namely Anglo-Indians, migrated in large numbers to Australia. As Sarwal underlines, they did so as British subjects, "exercising the choice to settle permanently in Australia" (2015, pp. 31). The Anglo-Indians were, in fact, among the first Asians to immigrate under the relaxation of entry rules to persons of mixed descent to Australia. It is true that the intake of indentured workers from South Asia and China began at the same time, but until the advent of the "Asian" economies on the global arena it went unnoticed (Sarwal 2013, pp. 5). The third wave of migrants began arriving in Australia immediately after the abandonment of the White Australia Policy (Immigration Restriction Act, 1901) was abandoned in 1973 with the introduction of the Multicultural Policy in 1975.

This "Global Migratory Phenomenon" (Rodrick in Nye, J. and Donahue, J. 2008) is portrayed in South Asian diasporic literature which, according to Tamara Mabbott 
Athique, has "in a relatively short space of time, achieved commercial and critical success" and "come of age" (2006, pp. 1). Nevertheless, even though there are relevant historical, anthropological and sociological studies available on the South Asian diaspora in Australia (Rashmere Bhatti, 2001; Purushotttama Bilimoria, 1996; R.S. Gabbi, 1998; Adrian Gilbert, 2009; Vijaya Joshi, 2000; Pamela Rajkowski, 1987; Joyce Westrip and Peggy Holroyde, 2010), very few have dealt with South Asian literature on the South Asian diaspora in Australia (Sarwal 2013, pp. 34). As Sarwal argues, "there are only nominal critical articles or dissertations on South Asian diasporic literature published in Australia and most themes remain under-explored" (2013, pp. 43) causing the South Asian diasporic writer "anxiety of invisibility" (Lal in Madan 2009). These include Cynthia Vanden Driesen's and I.H. Vanden Driesen's Celebrations: Fifty Years of Sri Lanka-Australia Interactions (1997); Glenn D'Cruz's PhD thesis 'Representing AngloIndians: A Genealogy Investigation" (1999); Mohit Manoj Prasad's PhD Thesis "IndoFijian Diasporic Bodies: Narratives in Text, Image, Popular Culture, and the Lived Everyday in Fiji and Liverpool, Sydney, Australia" (2005) and "Roots \& Routes: Politics of Location in Short Stories of South Asian Diaspora in Australia" (2010) by Amit Sarwal, but to name a few. Mostly, these authors explore the process of displacement and dislocation of identities through migration, journey, settlement, and nostalgic returns where characters' struggle to negotiate new spaces within Australia. These migratory experiences have created diasporic locations which need to be read and explored within new and specific interpretative frameworks, since the migrant as a subject influenced by political, economic and cultural factors has the right to self-identification. Athique's thesis on South Asian Diaspora literature in Australia "Textual Migrations: South AsianAustralian Fiction" (2006), for example, makes a new contribution to diversifying the field of criticism of diaspora by analyzing a set of texts (Christopher Cyrill, Suneeta Peres da Costa, Chitra Fernando, Sudesh Mishra, among others) that operate across local, national and transnational literary contexts. Yasmine Gooneratne explains the reasons why authors such as Mena Abdullah, an author who has achieved substantial recognition in Australia, is not well known abroad: "This is possibly because, although she is Australia-born, the experiences she writes about place her inevitably on the 'periphery,' and beyond the line that has hitherto lovingly enclosed Australia's 'traditional' authors in an enclave that is deemed 'central' to the nation's literary and cultural development" (1992, pp. 115).

Therefore, the metanarrative of Australian literature has to be challenged from different perspectives so as to have a literary negotiation of multiplicities. Feroza Jussawalla points out that, in order to survive, minorities in India had to subsume identity into hybridity, what she defines as "authentic Indianness" (in Fludernik 1989, pp. 200): "Hybridity is not a new condition in the postmodern era and is most definitely not a result of British postcoloniality. It is 'authentic Indianness'. And yet today, she continues ironically, fifty years after independence, ethnic identities are pulling India apart in their effort to recover their "authenticities" (in Fludernik 1989: 200). Diaspora should then be seen, following Celia Genn, "less a substantive bounded entity or ethno-cultural fact" (in Raghuram, Parvati 2008, pp. 252) than as an "idiom, a stance, a claim ... a way of formulating ... identities and loyalties" (Brubaker 2005, 12-13). The term, as we know, has become an umbrella used to shelter "intellectual, cultural and political agendas" (Brubaker 2005, pp. $1)$. 
There is then an unavoidable planetary conviviality in Australia as a result of the palimpsest resulting from colonialism and migration. Michelle de Kretser's Questions of Travel (2013) and Suneeta Peres da Costa's Homework (1999) name what for their characters is the authentic Australianness in the contemporary entangled milieu. Both authors' literary endeavour is far from catering to potential readers' demands for palatable exotica, avoiding anglicising and monogenising, and searching for "the location in which the self is at home" (George 1996, pp. 3). In Homework (1999) Suneeta Peres da Costa's presents the heart-breaking story of a little girl's struggle to survive a dysfunctional and chaotic family. Defined by many as an extraordinary debut infused with a Goan spice, Homework is only her first major publication, for she had actually been writing for years and had stage and radio plays produced and performed in Australia; the novel won her the 1997 Ulitarra Short Story Competition and was the runner up in the 1998 HQ/Flamingo Short Story Competition. This first novel about an Indian family who migrated to Australia portrays a young character gifted with a tragicomic personality. Indeed we first get to know that this intradiegetic omniscient narrator, Mina Pereira, was born with "protuberances, no bigger than finger tips" (Peres 1999, pp. 3) on her skull, and no matter what surgery doctors attempted, they kept growing back. These nodes, which act as feelers, accentuate Mina's emotional awareness. When consulted, one surgeon does not see much of a problem, though he does admit that Mina "might be a little sensitive, that's all. There are enough nerve endings in those things for lightning to strike them!" (Peres 1999, pp. 5-6). Over time Mina comes to think of them as her "feelers" through which she receives a heightened perception of the emotions flowing through the atmosphere around her: Mina's mother, a palliative physician, suffers from a breakdown leading onto an irrational obsession with birds, to the point of trying to become one. Her father, a loafer and dissident, has a printing press in their garage where he publishes a triannual publication on Goan liberation. Meanwhile, Mina's genius sister, Deepa, is so brainy that she calculates tax returns at the age of three. Shanti, the youngest, and the only "normal" one, sits in front of the TV all day watching cartoons. Mina is, within this convulsed household, a mutant: "You're a mutant, Mina, that's what you are!" (Peres 1999, pp. 9), with antennae that allow her to see farther than those who are around her. The double boundary her family inscribes, India-Australia, becomes a plural boundary for Mina. If Martin Heidegger highlights how "A boundary is not that at which something stops but, as the Greek recognized, the boundary is that from which something begins its presencing" (Heidegger in Bhabha 1994, pp. 1), Peres da Costa begins a "presencing" of a plural boundary that erases the t/here. Mina, whom when looking at a tin of California Sunshine, thinks about her mother complaining that "the Sydney sun never lasted long enough for her" (Peres 1999, pp. 14), and how “... I myself could remember gazing upon Mum's face as she and I had walked the streets of her Bombay youth bathed in such an illumination" (Peres 1999, pp. 15), when asked where she is from, points on the map that shows Asia and the Pacific, resting her hand "on the saggy soft breast of India" (Peres 1999, pp. 72), and Australia “('But we were born here -')" (Peres 1999, pp. 79-80). Mina, second generation South Asian-Australian was breast fed, "when multiculturalism had just, only just, made it to St. Sophia” (Peres 1999, pp. 156). She describes her mother's nipples as "imperceptible marks" (Peres 1996, pp. 72) which might represent the core trunk of the banyan tree I have before referred to but which through her diasporic misadventures is blurred and many other aerial roots fill up her existence enriching her planetary conviviality. The "presencing" of two geographical borders becomes the 
inscription of a plural territory of nomadization (Braidotti 1994) which Mina, thanks to her antennae, inhabits and disseminates.

A decade after Homework was published, Michelle de Kretser was awarded with the prestigious for Questions of Travel (2013), which draws two very different lives, those of Australian Laura and Sri Lankan Ravi. Michelle de Kretser was born in Sri Lanka and migrated to Australia when she was fourteen. Significantly, she does not use her hyphenated identity (Sri Lankan-Australian) to promote her work and she does not consider that being a migrant is limiting (Sarwal 2010, pp. 49) nor does she perceive herself as one. Like Chandani Lokugé, as a writer, she feels that a "migrant's double vision" is one of the most energetic areas of the creative process because you have a range of cultures from which to draw and you know each one rather well, which means you are not really strange to it and at the same time you are little distance (in Sarwal 2010, pp. 49). Both Laura and Ravi inhabit a world which de Kretser defines, at first, as "full of people who don't belong where they end up and long for the places where they did" (de Kretser 2013, pp. 125). Laura travels the world before returning to Sydney, where she works for a publisher of travel guides. Ravi, on the other hand, dreams of being a tourist until he is driven from Sri Lanka to Australia by a dreadful act of political slaughter. Laura when arriving in London discovers a country she is already familiarized with:

She looked at a bridge, and what she saw wasn't balustrade and arch but the embodiment of a sonnet. As for the monuments, they were iconic from tea towels. Then came a red-purple tree, magisterial in a park. Laura had never seen another like it and she recognised it at once-copper beeches were always turning up in novels. That was what it meant to be Australian: you came to London for the first time and discovered what you already knew. (de Kretser 2013, pp. 57).

However, arriving in Australia proved a contrasting experience for Ravi, "[ $\mathrm{t}$ ]he beaches, couched between headlands and devoid of coconut palms, didn't correspond at all to Ravi's notion of a coast" (de Kretser 2013, pp. 288-289). Robert McCrum suggests that "Part of de Kretser's point seems to be that the privileged travellers of the affluent West share a travel heritage, a way of looking and of describing that makes the world seem navigable and knowable: its horrors and injustices comfortably accommodated with the solipsism of the individual traveller' (McCrum 2013). De Kretser aims to go a step farther giving voice to a character, Ravi, who claims that "The world has shrunk ... From New York to Negombo, life would be digital and linked ... He said, 'Soon everyone will be a tourist" (de Kretser 2013, pp. 138). Both stories intertwine and have an Indian scent that lightly season the story, but it is never the main flavour. Beneath the project of this novel is the question of how such different stories can be brought into a single and coherent narrative (McCrum 2013). The answer is that they cannot, and this, following McCrum, is the central enigma of our globalised world. Laura and Ravi may find themselves sharing the same space, making common friends, but they will always be on different routes and have different roots. Crossing paths, they develop a work-place friendship before Laura departs on a visit to Sri Lanka just before the 2004 tsunami, with plans to meet up with Ravi, who had decided to return home, having rejected the security of his expatriate life. This is, in my opinion, the key message of this work. Both Laura and Ravi have distinct 
roots and follow diverse routes, that is, they are plural nomadic subjects searching for a third space which does not constrain them. Laura sees herself as "between two destinations, she was virtual, she was online, she was on the phone. She was a voice on a machine, she was here not there" (de Kretser 2013, 183). The environmental event, the tsunami of December $26^{\text {th }} 2004$ de Kretser ends the novel with, is a coup de théâtre which offers an apocalyptic end. The brutal damages metaphorically represent a tabula rasa which erases the inbetweenness that places Laura and Ravi here and there, seeming to advocate for an "empty space": "But it is only the nomads who possess the "war machine' - a phrase used by both Hubac and Deleuze-and-Guattari. The goal of this machine is to restore land to nomadism, to bring everything back to 'empty space', the primordial tabula rasa" (Cristopher Miller in Genosko 2001, pp. 1138). Which means that in the case of Questions of Travel, the "super-ego-status" Brady referred to, is still in existence.

The space of planetary conviviality, in the case of Homework, and the utopic tabula rasa, in Questions of Travel, represent the "'interruptive, interrogative, and enunciative' space where negotiation takes place; 'a mode of articulation, a way of describing a productive ... space that engenders new possibilities" (Bhabha 1994). Literature, following David Carter "is not just a set of individual texts or authors but rather a set of institutions and institutional practices which regulate the making and transmission of (literary) meanings in a given society" (1997, pp. 18). Undoubtedly, authors such as Peres da Costa and de Kretser are examples of how Australians of South Asian lineage have become part of the Australian social order at the same time that they deconstruct the norm. With their literary works they raise uneasy questions; not in vain does de Kretser entitle her novel Questions of Travel, since she is well aware of the need to redefine and review the Australian literary canon and, with it, the very meaning of Australianness. A canon and an identity which, according to Australian novelist of Bangladeshi origin, Adib Khan, had had to account for the "acceleration in the proliferation of cross-cultural voices in fiction' occurring in the last decades of the $20^{\text {th }}$ century an incorporate "the diversity that reflects the type of society that Australia is" (2002, pp. 3). The concurrence of such a wide array of literary voices is what, ultimately, calls for a planetary conviviality at the point at which true dialogue begins, for, in Bill Ashcroft's terms, "modernity, rather than a hierarchical and homogenizing western influence, is actually multiple and rhizomic" (2015, pp. 8).

\section{Works cited:}

Aschcroft, Bill. "Towards a Postcolonial Aesthetics". Journal of Postcolonial Writing. Routledge, 2015.

Athique, Tamara Mabbott. "Textual Migrations: South Asian-Australian Fiction”. PhD Thesis. U of Wollongong, 2006.

Bhabha, Homi. The Location of Culture. New York, Routledge, 1994.

Braidotti, Rosi. Nomadic Subject. Embodiment and Sexual Difference in Contemporary Feminist Theory. New York, Columbia UP, 1994. 
Brubaker, Rogers. “The 'Diaspora' Diaspora”. Ethnic and Racial Studies, 28 (1), 2005, pp. 1-19.

Carter, David. “Literary Canons and Literary Institutions”. Southerly 57.3, 1997, pp. 1637.

Corkhill, Annette Robyn. The Immigrant Experience in Australian Literature. Melbourne, Academia P, 1995.

Dasgupta, T. Political Economy of Race Gender and Class looking at South Asian Women in Canada. Canadian Ethnic Studies, 26(1), 1994, pp. 59-73.

de Kretser, Michelle. Questions of Travel. 2013. London, Allen\&Unwin, 2014

European Journal of Psychotherapy \& Counselling. "Levinas and the Other in Psychotherapy and Counselling.7:1-2,2005, pp. 1-5.

Fludernik, Monika (ed.). Hybridity and Postcolonialism. Twentieth-Century Indian Literature. Tubinen, Stauffeburg Verlag, 1989.

Foster, Richard. "A Review A review of Camels, Ships, Trains: Translation Across the 'Indian Archipelago' 1860-1930, by Samia Khatun". The South Asian Diaspora in Australia. http://dissertationreviews.org/archives/6656. Accessed 16 Oct. 2014.

Genosko, Gary (ed.). Deleuze and Guatarri. Critical Assessments of Leading Philoshopers. New York, Routledge, 2001.

George, Rosemary Marangoly. The Politics of Home: Postcolonial Relocations and Twentieth Century Fiction. Cambridge, Cambridge UP, 1996.

Gilroy, Paul. Postcolonial Melancholia. New York, Columbia University Press, 2005.

Goonerate, Yasmine. "Mena Abdullah, Australian Writer" in Striking Chords: Multicultural Literary Interpretations. Edited by Sneja Gunew and Kateryna O. Longley. North Sydney, NSW,Allen \& Unwin, 1992, pp. 115-124.

Heise, Ursula. Sense of Place and Sense of Planet: The Environmental Imagination of the Global. Oxford, Oxford University Press, 2008.

Jones, Gail. "Veronica Brady”, Journal of Australian Studies, 21:54-55, 1997, pp. 136149.

Khan, Adib. "Trends in Australian Fiction". Kosmopolis 2 (2002). Centre de Cultura Contemporània de Barcelona. http://www.cccb.org/rcs_gene/Adib_Khaneng.pdf. Last Accessed 10 Feb. 2014.

Kurian, G. "South Asians in Canada". International Migration, 29 (3), 1991, pp. 421433.

Lenz, Günter H. "Symposium: Redefinitions of Citizenship and Revisions of Cosmopolitanism-Transnational Perspectives". Journal of Transnational American Studies, 3 (1), 2011, pp. 39-46.

Madan, Karuna. "Diaspora Indians Suffer from the Anxiety of Invisibility". China View. Press Release 10.08.2009. http://english.cri.cn/6966/2009/08/14/2001s508882.htm. Last Accessed 5 May 2014. 
McCrum, Robert. "Summer voyages: Questions of Travel by Michelle de Kretser". In The Guardian, 15.07.2013. http://www.theguardian.com/books/booksblog/2013/jul/15/michelle-kretserquestions-of-travel-summer-reading. Last Accessed 9 Sept. 2014.

Mitchell, Adrian and Cynthia Vanden Driesen (eds.). New Directions in Australian Studies. New Delhi, Prestige Books, 2000.

Nye, Joseph S. And John D. Donahue eds. Governance in a Globalising World. Massachusetts, Brookings Intitution Press, 2000.

Peres da Costa, Suneeta. Homework. 2000. London, Bloomsbury,1999.

Prassad, Leela (ed.). Live Like the Banyan Tree. Images of the Indian American Experience. The Balch Institute for Ethnic Studies, 1995.

Raghuram, Parvati et al (eds.). Tracing and Indian Diaspora. Context, Memories, Representations. London, Sage Publications Inc, 2008.

Riaz, A. Religion and Politics in South Asia. London, Routledge, 2010.

Rushdie, Salman. Imaginary Homelands: Essays and Criticism, 1981-1991. New York, Viking, 1991.

---. Shame. New York, Adventure, 1984.

Sarwal, Amit. Labels and Locations. Gender, Family, Class and Caste. The Short Narratives of South Asian Diaspora in Australia. Cambridge Scholars Publishing, 2015

---. Bridging Imaginations. South Asian Diaspora in Australia. New Delhi, Readworthy, 2013.

---. "Roots and Routes: Politics of Location in the Short Stories of the South Asian Diaspora in Australia." Unpublished PhD dissertation, Jawaharlal Nehru University, New Delhi, 2010.

Spivak, Gayatri Chakravorty. Death of a Discipline. New York, Columbia University Press, 2003.

Tinker, Hugh 1977. The Banyan Tree: Overseas Emigrants form India, Pakistan and Bangladesh. Oxford, Oxford UP.

Bio note: Alejandra Moreno Álvarez holds a PhD in Women's Studies from the University of Oviedo. She has been a research fellow at Rutgers University, Cornell University and the University of Leeds, among others. Currently, she is a Senior Lecturer in the English Department of the University of Oviedo. Her teaching and research is centered in Literatures in English Language and Feminist and Postcolonial Theory. She is the author of Lenguajes comestibles: Anorexia, bulimia y su descodificación en la ficción de Margaret Atwood y Fay Weldon (Edicions UIB, 2009); El lenguaje trasgresor de las Ciborgs Literarias (ArCiBel Editores,2011) and Ambai: Un movimiento, una carpeta, algunas lágrimas / A movement, a folder, some tears (KRK, 2011). 